IZA DP No. 10010

Faculty Service Loads and Gender: Are Women Taking Care of the Academic Family?

Cassandra M. Guarino

Victor M. H. Borden

June 2016 


\title{
Faculty Service Loads and Gender: Are Women Taking Care of the Academic Family?
}

\author{
Cassandra M. Guarino \\ University of California Riverside \\ and IZA \\ Victor M. H. Borden \\ Indiana University Bloomington
}

Discussion Paper No. 10010

June 2016

IZA
P.O. Box 7240
53072 Bonn
Germany

Phone: +49-228-3894-0

Fax: +49-228-3894-180

E-mail: iza@iza.org

\begin{abstract}
Any opinions expressed here are those of the author(s) and not those of IZA. Research published in this series may include views on policy, but the institute itself takes no institutional policy positions. The IZA research network is committed to the IZA Guiding Principles of Research Integrity.

The Institute for the Study of Labor (IZA) in Bonn is a local and virtual international research center and a place of communication between science, politics and business. IZA is an independent nonprofit organization supported by Deutsche Post Foundation. The center is associated with the University of Bonn and offers a stimulating research environment through its international network, workshops and conferences, data service, project support, research visits and doctoral program. IZA engages in (i) original and internationally competitive research in all fields of labor economics, (ii) development of policy concepts, and (iii) dissemination of research results and concepts to the interested public.
\end{abstract}

IZA Discussion Papers often represent preliminary work and are circulated to encourage discussion. Citation of such a paper should account for its provisional character. A revised version may be available directly from the author. 
IZA Discussion Paper No. 10010

June 2016

\section{ABSTRACT \\ Faculty Service Loads and Gender: Are Women Taking Care of the Academic Family?}

This paper investigates the amount of academic service performed by female versus male faculty. We use 2012 data from an online annual performance reporting system for tenured and tenure-track faculty at two campuses of a large public, Midwestern university as well as 2014 data from a large national survey of faculty at more than 140 institutions. We find evidence in both data sources that women faculty perform significantly more service than men, controlling for rank, race/ethnicity, and field or department. Our analyses suggest that the male-female differential is driven primarily by internal service - i.e., service to the university, campus, or department - rather than external service - i.e., service to the local, national, and international communities.

JEL Classification: $\quad 123$

Keywords: faculty, gender

Corresponding author:

Cassandra M. Guarino

Graduate School of Education

University of California, Riverside

2123 Sproul Hall

Riverside, CA

USA

E-mail: Cassandra.guarino@ucr.edu 


\section{Introduction}

A number of studies have shown that women and men employed in academia experience and react to their work environments differently-largely in ways that are unfavorable to women. Research has indicated that women receive lower salaries (Carr et al. 2015, Toutkoushian \& Conley 2005) and fewer resources such as research space (Chisholm et al. 1999). Moreover, faculty women do more housework at home than their male counterparts (Scheibinger \& Gilmartin 2010) and experience more difficulty in achieving work-life balance (O'Laughlin \& Bischoff 2005). In the past, women faculty have been found to be less likely to be promoted to the rank of full professor, even after controlling for productivity and human capital (Toutkoushian 1999, Perna 2001), though it is not known whether this imbalance has been redressed in recent years.

This study adds to the literature on gender differences in academia by investigating differences in faculty service loads. The amount of service performed by women versus men is an issue that has not received much attention in the prior literature but that has an important impact on the career of any academic. Service is typically a time-consuming feature of the job of an academic and typically factors into faculty performance evaluations, alongside research and teaching. However, service is generally rated as less important than either research or teaching and is less likely to lead to career advancement within an institution. In research intensive institutions, the publication of research is a primary vehicle for advancement for the vast majority of faculty, and in non-doctoral granting institutions, teaching is emphasized more heavily (Street, Baril, \& Benke, 1993). Service, while a factor in performance reviews, is generally ranked after research and teaching in importance. In order to protect the career trajectories of junior faculty, tenured faculty are expected to perform more service than pre-tenure faculty, who are, in theory, encouraged to focus more heavily on research.

Service can be characterized according to two main categories that we refer to as internal and external service. Internal service consists of service to one's department, school, or university in 
activities relating to faculty governance, faculty recruitment, evaluation, and promotion, student admissions and scholarships, program supervision, development and marketing, internal awards, etc. Individuals who assume defined administrative roles, such as department chairs, deans, etc., are compensated for their service, but the vast majority of faculty receive no compensation and are expected to contribute as good citizens to the academic community as part of their job.

Uncompensated internal service is usually acknowledged and factored into performance reviews, but, as we have mentioned above, generally carries less weight than research or teaching.

External service consists of service outside of campus - to the profession and to the local, state, regional, national, and international communities. In terms of career advancement, external service normally generates greater value to the individual faculty member, as it provides visibility and enhances his or her reputation among a broad group of peers. Such external recognition could result in better external job offers, which can be used either to move up in a different institution or to raise the salary or status of a faculty member in his or her home institution. In some academic disciplines and within some institutions that include community engagement as a core mission, certain types of external service are also considered an integral part of evaluation, including promotion and tenure, as it demonstrates the impact of the scholar's work on communities.

In this study, we use two large data sets to investigate the relative amounts and types of service performed by women and men in academia and find that women, regardless of rank, discipline, or racial-ethnic category, perform more service than their male counterparts. When we investigate differences in internal versus external service, we find that women perform significantly more internal service than men, but that there are no statistically significant differences in the amount of external service performed. We also find that certain disciplines and schools perform more service than others. 


\section{Prior Research on Gender and Faculty Service}

A few prior studies have empirically investigated the gender-service connection at institutions of higher education. Bellas and Toutkoushian (1999), employ data from the 1993 National Study of Postsecondary Faculty (NSOPF) to examine differences in how men and women faculty allocate time across teaching research and service. Their study followed earlier ones conducted using the 1988 NSOPF study that demonstrated that women faculty spend more time in teaching and service activities than did their male counterparts across all types of institutions (Russell et al. 1991) and especially at research universities (Singell et al. 1996). Their regression model controlled for individual, job and institutional characteristics and included three definitions of work time: paid hours only; adding in unpaid work hours at the home institution; and further adding in unpaid service hours outside the institution. While finding differences in time devoted to teaching (women higher) and research (men higher), Bellas and Toutkoushian did not find significant differences in time spent in service activities. They note however, that there are differences in service load by rank (lower ranks entailing more service), and women are disproportionately represented at the lower ranks.

Porter (2007) employed data from the 1999 National Study of Postsecondary Faculty (NSOPF) to examine factors affecting the number of committees on which faculty serve and the estimated time devoted to such service. Porter's study also differentiated by types of committee, categorized as: curriculum; governance; personnel; and other. After controlling for rank, age, and academic field, Porter found mixed effects for race and gender, depending on institutional type. Females at research universities were more likely to serve on governance committees, while females at comprehensive universities served on fewer personnel committees on average. The largest differences were found at doctoral universities and liberal arts colleges, where females served on 25 percent more committees than did their male counterparts. Porter did not find gender differences in time spent working on committees after controlling for number of committees. 
Focusing specifically on faculty at research universities in science and engineering disciplines, Link et al. (2007) employed a stratified sample (equal numbers of males and females) using data from the 2004-05 National Science Foundation Survey of Academic Researchers to examine the relationship of promotion, tenure and gender on faculty time allocation. After controlling for rank/tenure status, race, and years of experience, Link and his colleagues found that, using either mean hours or fraction of overall time, males devoted more time to research and less to service than their female counterparts.

Misra and colleagues (2011) report on the results of a survey of 350 faculty at University of Massachusetts, Amherst focusing on time use. They found that at the associate professor level, women devoted more hours to service and fewer hours to research than men, a phenomenon they termed the "gendered gully of service." Their survey included perceptions of service as well, and they found that women had no greater preference for service than men.

In reviewing the empirical literature on inequities in service loads, Bird and colleagues (2004), note that institutional initiatives to redress such inequities often involve the creation of task forces and study groups, predominantly comprised of women faculty, to conduct rigorous, time-consuming studies. They refer to such work as “...'institutional housekeeping' because it represents the invisible and supportive labor of women to improve women's situation within the institution" (p. 195). They note with irony how such opportunities, although disruptive of disciplinary research, enable women faculty to connect with each other in meaningful ways. Conversely, male faculty members find community among male colleagues with similar research-oriented career trajectories.

\section{Data}

In this study, we use two data sets to investigate the relative amounts of service performed by women and men. The first is specific to a particular university system and contains detail regarding the type of service performed. The other is a national data set comprised of respondents to a survey of faculty at a large number of institutions of higher education. We describe these data sets below. 
The first source of data for this study comes from online faculty yearly activity reports, which we will henceforth refer to as FYAR, at the two large research-intensive campuses of a large, Midwestern public multi-campus university. One of the campuses is a traditional research intensive campus, and the other is an urban campus.

The annual reports are required and are used in yearly faculty evaluations. Salary increases are predominantly based on a merit evaluation based on the activity reports, thus an incentive exists on the part of faculty to list all research, teaching, and service activities performed during the year.

We use data from 2012 for full-time tenure-track faculty, 34.8\% percent of whom are female. The full sample consists of 2,041 faculty. However, we exclude faculty who hold administrative positions, such as deans, associate deans, assistant deans, department chairs, etc., since these service activities are generally compensated with position pay or decreased teaching responsibilities. After these exclusions and the exclusion of observations with missing data, the total number of faculty is 1,401 . Of these, $37 \%$ are female. The breakdown across the two campuses is $69 \%$ in the traditional research campus and $31 \%$ in the urban campus. ,

Included in the data are demographic characteristics such as gender and race-ethnicity as well as rank (assistant, associate, or full professor) department, school, and campus.

Reporting of service activities is broken down into several subcategories, which we aggregate into "internal" and "external." In reporting each service activity performed, faculty choose a "type" of service from a pull-down list in addition to providing a detailed explanation of the specific activity. We used the pre-set categories to determine whether service was internal or external. Service activities reported in categories labeled department, school, campus, and university were classified as internal service. Service activities reported in categories labeled community, economic development, professional organizations, life sciences, regional, state, national, and international were classified as 
external service. Service activities must be classified as belonging to one of these categories and cannot be double-counted or jointly classified.

The following table describes the FYAR data:

Table 1. Summary of Variables for Full-time Tenured or Tenure-track Faculty in the FYAR, 2012

\begin{tabular}{|c|c|c|c|c|c|}
\hline Variable & Obs & Mean & Std. Dev. & Min & Max \\
\hline \multicolumn{6}{|l|}{ Number of service activities } \\
\hline Total service & 1,401 & 11.58 & 8.52 & 0 & 78 \\
\hline Internal service & 1,401 & 6.59 & 5.49 & 0 & 48 \\
\hline Service to department & 1,401 & 2.64 & 2.89 & 0 & 30 \\
\hline Service to school & 1,401 & 1.79 & 2.88 & 0 & 32 \\
\hline Service to campus & 1,401 & 1.51 & 2.40 & 0 & 22 \\
\hline Service to university & 1,401 & 0.65 & 1.50 & 0 & 24 \\
\hline External service & 1,401 & 4.99 & 5.00 & 0 & 34 \\
\hline Service to community & 1,401 & 0.67 & 1.46 & 0 & 13 \\
\hline Service to state & 1,401 & 0.09 & 0.41 & 0 & 5 \\
\hline Service to region & 1,401 & 0.06 & 0.31 & 0 & 5 \\
\hline National service & 1,401 & 0.81 & 1.60 & 0 & 13 \\
\hline International service & 1,401 & 1.09 & 2.69 & 0 & 29 \\
\hline Service for economic development & 1,401 & 0.02 & 0.20 & 0 & 5 \\
\hline Service to life sciences & 1,401 & 0.09 & 0.84 & 0 & 24 \\
\hline Service to professional org & 1,401 & 2.16 & 3.28 & 0 & 26 \\
\hline \multicolumn{6}{|l|}{ Gender } \\
\hline Female & 1,401 & 0.37 & 0.48 & 0 & 1 \\
\hline \multicolumn{6}{|l|}{ Rank } \\
\hline Assistant professor & 1,401 & 0.28 & 0.45 & 0 & 1 \\
\hline Associate professor & 1,401 & 0.36 & 0.48 & 0 & 1 \\
\hline Full professor & 1,401 & 0.37 & 0.48 & 0 & 1 \\
\hline \multicolumn{6}{|l|}{ Race/ethnicity } \\
\hline White & 1,401 & 0.77 & 0.42 & 0 & 1 \\
\hline Black/African American & 1,401 & 0.05 & 0.23 & 0 & 1 \\
\hline Hispanic/Latino/Latina & 1,401 & 0.03 & 0.18 & 0 & 1 \\
\hline Asian/Asian American & 1,401 & 0.13 & 0.34 & 0 & 1 \\
\hline Other race & 1,401 & 0.02 & 0.12 & 0 & 1 \\
\hline \multicolumn{6}{|l|}{ School/field } \\
\hline Liberal arts & 1,401 & 0.15 & 0.35 & 0 & 1 \\
\hline Education & 1,401 & 0.08 & 0.27 & 0 & 1 \\
\hline Business & 1,401 & 0.08 & 0.28 & 0 & 1 \\
\hline Law & 1,401 & 0.01 & 0.11 & 0 & 1 \\
\hline Public policy & 1,401 & 0.03 & 0.17 & 0 & 1 \\
\hline Fine arts & 1,401 & 0.10 & 0.31 & 0 & 1 \\
\hline Social science & 1,401 & 0.17 & 0.38 & 0 & 1 \\
\hline
\end{tabular}




\begin{tabular}{llllll} 
STEM (Natural Sciences/Math) & 1,401 & 0.22 & 0.41 & 0 & 1 \\
Communications/journalism & 1,401 & 0.04 & 0.19 & 0 & 1 \\
Tourism/philanthropy & 1,401 & 0.01 & 0.08 & 0 & 1 \\
Campus & & & & & \\
Traditional research & 1,401 & 0.69 & 0.46 & 0 & 1 \\
\hline
\end{tabular}

Source: FYAR data, 2012, two campuses at a large Midwestern university

FSSE Data: The other source of data for the study is the Faculty Survey of Student Engagement (FSSE) from 2014, a web-based survey designed to complement the National Survey of Student Engagement (NSSE). The primary purpose of the FSSE survey is to measure faculty members' perceptions and experiences of student engagement. However, the survey also includes responses from faculty as to how they spend their time across types of professorial activities (teaching, student advising, research, and service) The 2014 FSSE survey includes responses from just under 19,000 faculty representing 143 bachelor's-degree granting institutions, primarily located in the U.S. (three were in Canada, and one was an American university located abroad). Contact information is provided to FSSE, which administers the survey online.

For the present analysis, the researchers requested FSSE data for full-time tenured and tenuretrack faculty ranked assistant, associate, or full professor. Just under $40 \%$ of FSSE respondents satisfied these criteria, yielding an initial sample of 7,398 tenured and tenure-track faculty, among which 6,875 $(93 \%)$ have a reported value for gender. About 42 percent are women, and 24 percent work in institutions that can be classified as research-intensive.

Service was reported as a categorical variable estimating the average number of hours per week with the following possible responses: $0,1-4,5-8,9-12,13-16,17-20,20-30$, and more than 30 . To construct a "continuous" outcome variable from these responses, we assigned the value 0 to the first category, the value 35 to the highest category, and took the midpoint of each category in between. However, we also used the original categorical variable in an ordered logit, as reported in the results section below. 
The following table provides descriptive information on the sample of faculty who reported a

gender category:

Table 2. Summary of Variables for Full-time Tenured or Tenure-track Faculty with a Reported Value for Gender in the FSSE, 2014

\begin{tabular}{|c|c|c|c|c|c|}
\hline Variable & Obs & Mean & $\begin{array}{l}\text { Std. } \\
\text { Dev. }\end{array}$ & Min & Max \\
\hline Service hours per week & 6,817 & 8.91 & 7.32 & 0 & 35 \\
\hline Female & 6,875 & 0.42 & 0.49 & 0 & 1 \\
\hline \multicolumn{6}{|l|}{ Rank } \\
\hline Assistant professor & 6,875 & 0.29 & 0.46 & 0 & 1 \\
\hline Associate professor & 6,875 & 0.34 & 0.47 & 0 & 1 \\
\hline Full professor & 6,875 & 0.37 & 0.48 & 0 & 1 \\
\hline \multicolumn{6}{|l|}{ Race/ethnicity } \\
\hline White & 6,811 & 0.77 & 0.42 & 0 & 1 \\
\hline Asian/Asian American & 6,811 & 0.07 & 0.25 & 0 & 1 \\
\hline Black/African American & 6,811 & 0.06 & 0.23 & 0 & 1 \\
\hline Hispanic/Latino/Latina & 6,811 & 0.04 & 0.19 & 0 & 1 \\
\hline Alaskan/Native American & 6,811 & 0.01 & 0.11 & 0 & 1 \\
\hline Pacific Islander & 6,811 & 0.00 & 0.05 & 0 & 1 \\
\hline Other race & 6,811 & 0.02 & 0.15 & 0 & 1 \\
\hline \multicolumn{6}{|l|}{ Disciplinary area } \\
\hline Arts and Humanities & 6,841 & 0.28 & 0.45 & 0 & 1 \\
\hline Biological Sciences & 6,841 & 0.10 & 0.30 & 0 & 1 \\
\hline Physical Sciences & 6,841 & 0.14 & 0.35 & 0 & 1 \\
\hline Social Science & 6,841 & 0.15 & 0.35 & 0 & 1 \\
\hline Business & 6,841 & 0.07 & 0.26 & 0 & 1 \\
\hline Communications & 6,841 & 0.03 & 0.18 & 0 & 1 \\
\hline Education & 6,841 & 0.07 & 0.25 & 0 & 1 \\
\hline Engineering & 6,841 & 0.05 & 0.22 & 0 & 1 \\
\hline Health & 6,841 & 0.05 & 0.22 & 0 & 1 \\
\hline Social Services & 6,841 & 0.02 & 0.15 & 0 & 1 \\
\hline Other & 6,841 & 0.04 & 0.19 & 0 & 1 \\
\hline \multicolumn{6}{|l|}{ Institution type } \\
\hline Research 1 & 6,875 & 0.24 & 0.43 & 0 & 1 \\
\hline
\end{tabular}




\section{Methods}

We investigate service load differences, first examining raw differences and then controlling for rank and other variables, such as race/ethnicity and school or discipline. We use the following multiple regression model to investigate our question:

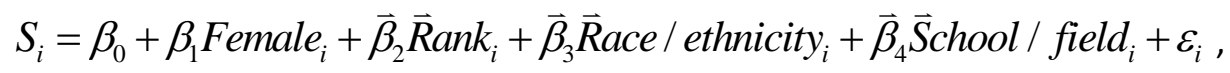

where $S_{i}$ is a dependent variable measuring the amount of service that faculty member $i$ reports having engaged in, rank is a vector composed of indicators for associate and full professor status (omitted category is assistant), race-ethnicity is a vector composed of indicators for Black, Hispanic, Asian, and other (omitted category is White), and school/field is a vector composed of indicators for different schools and field areas within the university (omitted category is "Liberal Arts" in the case of the FYAR data and "Arts and Humanities" in the case of the FSSE data).

In the FSSE data, we ran an ordered logit specification using the original categorical variable as the dependent variable and also ran an OLS regression using the recoded "continuous" variable as the dependent variable to enable us to have some sense of the magnitude of time differences. We also used institution-level fixed effects in the FSSE regressions to control for differences in the characteristics of institutions, such as research intensity or public-private status, and we clustered the standard errors at the institutional level, as well.

In some specifications, we entered interactions between the female variable and the other variables in the model to assess whether the gender differential was more concentrated at particular ranks, among particular racial-ethnic groups, or in particular schools.

\section{Results}

The raw difference in the amount of service performed by women versus men in academia is approximately 1.6 more activities per year in the FYAR and half an hour more per week in the FSSE, and 
the difference is statistically significant in both cases. Of course, since this could simply reflect gender differences in rank or field, multiple regression results are far more informative.

\section{Results from the FYAR Analysis}

Table 3 presents the results of the multiple regression analysis using the FYAR data controlling for rank, race/ethnicity, department, and campus. The results show that, according to self-reported numbers, female faculty perform, on average, 1.28 more service activities per year than male faculty and that this difference is driven largely by internal service activities. Women perform nearly one more full internal service activity annually than men.

Table 3. Regression of Number of Service Activities on Female and Controls

\begin{tabular}{|c|c|c|c|c|c|c|c|c|c|}
\hline \multirow[b]{2}{*}{ Variables } & \multicolumn{3}{|c|}{ Total Service } & \multicolumn{3}{|c|}{ Internal } & \multicolumn{3}{|c|}{ External } \\
\hline & $\mathrm{B}$ & SE & sig & $\mathrm{B}$ & SE & sig & $\mathrm{B}$ & SE & sig \\
\hline \multicolumn{10}{|l|}{ Gender } \\
\hline Female & 1.28 & 0.48 & $* *$ & 0.91 & 0.31 & $* *$ & 0.37 & 0.28 & \\
\hline \multicolumn{10}{|l|}{ Rank (ref. group Assistant) } \\
\hline Full & 1.71 & 0.58 & $* *$ & 0.72 & 0.38 & & 0.99 & 0.34 & $* *$ \\
\hline Associate & 2.06 & 0.57 & $* *$ & 1.66 & 0.36 & $* *$ & 0.40 & 0.33 & \\
\hline \multicolumn{10}{|l|}{ Race/Ethnicity (ref. group White) } \\
\hline Black/African American & -2.02 & 1.00 & $*$ & -1.00 & 0.64 & & -1.02 & 0.59 & \\
\hline Hispanic & 0.73 & 1.24 & & 0.60 & 0.80 & & 0.12 & 0.73 & \\
\hline Asian/Asian American & -1.33 & 0.69 & & -1.32 & 0.45 & $* *$ & -0.01 & 0.41 & \\
\hline Other, non-White & -0.63 & 1.80 & & -0.11 & 1.16 & & -0.52 & 1.06 & \\
\hline \multicolumn{10}{|c|}{$\begin{array}{l}\text { Disciplinary Area (ref. group Liberal } \\
\text { Arts) }\end{array}$} \\
\hline Education & 1.22 & 0.90 & & -0.15 & 0.58 & & 1.37 & 0.53 & $*$ \\
\hline Business & -2.94 & 0.89 & $* *$ & -2.28 & 0.57 & $* *$ & -0.66 & 0.53 & \\
\hline Law & -5.67 & 2.16 & $* *$ & -2.75 & 1.39 & $*$ & -2.92 & 1.27 & $*$ \\
\hline Public Policy & 4.32 & 2.32 & $* *$ & 3.55 & 0.85 & $* *$ & 0.77 & 0.78 & \\
\hline Fine Arts & -3.68 & 0.82 & $* *$ & -0.85 & 0.53 & & -2.83 & 0.48 & $* *$ \\
\hline Social Sciences & -2.19 & 0.69 & $* *$ & -1.44 & 0.45 & $* *$ & -0.75 & 0.41 & \\
\hline Natural Sciences/Math & -1.57 & 0.68 & $*$ & -1.30 & 0.43 & $* *$ & -0.27 & 0.40 & \\
\hline Communications/Journalism & 2.98 & 1.25 & $*$ & 0.75 & 0.80 & & 2.23 & 0.74 & $* *$ \\
\hline Public Health & 0.58 & 2.98 & & -0.01 & 1.92 & & 0.59 & 1.76 & \\
\hline \multicolumn{10}{|c|}{ Campus (ref. group Urban Research) } \\
\hline Traditional Research & -0.35 & 0.51 & & -0.53 & 0.33 & & 0.18 & 0.30 & \\
\hline
\end{tabular}




\begin{tabular}{|c|c|c|c|c|c|c|c|c|}
\hline Constant & 11.33 & 0.73 & $* *$ & 6.69 & $0.47 \quad * *$ & 4.64 & 0.43 & $* *$ \\
\hline $\mathrm{R}^{2}$ & 0.07 & & & 0.08 & & 0.06 & & \\
\hline $\mathrm{N}$ & 1401 & & & 1401 & & 1401 & & \\
\hline
\end{tabular}

Source: FYAR data, 2012, two campuses at a large Midwestern university

With regard to other covariates, we find that associates report performing more service than assistants or even full professors and that this is driven by internal service. Full professors exceed those in other ranks in external service. The disciplinary area showed stark differences in service activities, with faculty in business, law, fine arts, and the STEM fields reporting less service and public policy more service than those in the liberal arts.

To investigate gender differences further, we included interactions between the female variable and the various sets of other types of covariates. We investigated specifications with different sets of interactions and one that contained all interactions. These yielded little additional information, with some exceptions. There was some evidence to suggest that women in the public policy faculty performed significantly more service than men on that faculty and that Asian female faculty performed more service than Asian male faculty. When all interactions were included in the model the main effects and the individual interactions lost significance, but joint tests of significance of all variables containing the female indicator, whether on its own or in an interaction remained significant.

In addition, we conducted the regression analysis separately by service type. Tables 4 and 5 present the results for the internal and external service activities, respectively. Table 4 shows that women faculty report significantly more activity than their male counterparts in the "campus" service category, thus this particular area of service, rather than departmental, school, or university service (recall that the two institutions included in the data form part of a university system, thus "university" refers to service to the combined university system as opposed to one's own campus) appears to be the 
area driving the imbalance. Examples of campus service activities might be participation on campuswide committees, faculty councils, task forces, projects, etc.

Table 4. Regressions with Specific Internal Service Activity Categories as Dependent Variable

\begin{tabular}{|c|c|c|c|c|c|c|c|c|c|c|c|c|}
\hline \multirow[b]{2}{*}{ Variables } & \multicolumn{3}{|c|}{ Dept/Program } & \multicolumn{3}{|c|}{ School/College } & \multicolumn{3}{|c|}{ Campus } & \multicolumn{3}{|c|}{ University } \\
\hline & B & SE & sig & B & SE & sig & $\mathrm{B}$ & SE & sig & B & SE & sig \\
\hline \multicolumn{13}{|l|}{ Gender } \\
\hline Female & 0.14 & 0.16 & & 0.02 & 0.15 & & 0.60 & 0.13 & $* *$ & 0.15 & 0.09 & \\
\hline \multicolumn{13}{|l|}{ Rank } \\
\hline Full & -0.36 & 0.20 & & 0.31 & 0.19 & & 0.60 & 0.16 & $* *$ & 0.17 & 0.10 & \\
\hline Associate & 0.27 & 0.19 & & 0.50 & 0.18 & $* *$ & 0.71 & 0.16 & $* *$ & 0.19 & 0.10 & \\
\hline \multicolumn{13}{|l|}{ Race/Ethnicity } \\
\hline Black/Afr Amer & -0.72 & 0.34 & $*$ & 0.17 & 0.32 & & -0.38 & 0.28 & & -0.08 & 0.18 & \\
\hline Hispanic & -0.54 & 0.42 & & 0.65 & 0.39 & & 0.28 & 0.35 & & 0.21 & 0.22 & \\
\hline Asian & -0.39 & 0.24 & & -0.31 & 0.22 & & -0.57 & 0.19 & $* *$ & -0.05 & 0.12 & \\
\hline Other, non-White & -0.27 & 0.61 & & 0.16 & 0.57 & & 0.22 & 0.50 & & -0.22 & 0.32 & \\
\hline \multicolumn{13}{|l|}{ Disciplinary Area } \\
\hline Education & -1.13 & 0.31 & $* *$ & 1.36 & 0.29 & $* *$ & -1.08 & 0.25 & $* *$ & 0.70 & 0.16 & \\
\hline Business & -1.90 & 0.30 & $* *$ & 1.00 & 0.28 & $* *$ & -1.11 & 0.25 & $* *$ & -0.27 & 0.16 & \\
\hline Law & -1.30 & 0.73 & & 0.47 & 0.68 & & -1.65 & 0.60 & $* *$ & -0.27 & 0.39 & \\
\hline Public Policy & -2.32 & 0.45 & $* *$ & 5.49 & 0.42 & $* *$ & -0.15 & 0.37 & & 0.53 & 0.24 & \\
\hline Fine Arts & -0.71 & 0.28 & $*$ & 1.11 & 0.26 & $* *$ & -1.10 & 0.23 & $* *$ & -0.15 & 0.15 & $* *$ \\
\hline Social Sciences & -0.18 & 0.24 & & -0.79 & 0.22 & $* *$ & -0.56 & 0.19 & $* *$ & 0.10 & 0.12 & \\
\hline Natural Sci/Math & -0.05 & 0.23 & & -0.46 & 0.21 & & -0.68 & 0.19 & $* *$ & -0.11 & 0.12 & \\
\hline Commun/Journ & -0.88 & 0.42 & $*$ & 0.89 & 0.40 & $*$ & 0.57 & 0.35 & & 0.17 & 0.22 & \\
\hline Public Health & 0.27 & 1.01 & & 0.25 & 0.94 & & -0.36 & 0.83 & & -0.17 & 0.53 & \\
\hline \multicolumn{13}{|l|}{ Campus } \\
\hline Trad Research & 0.68 & 0.17 & $* *$ & -0.80 & 0.16 & $* *$ & -0.59 & 0.14 & $* *$ & 0.18 & 0.09 & $*$ \\
\hline Constant & 2.75 & 0.25 & $* *$ & 1.78 & 0.23 & $* *$ & 1.85 & 0.20 & $* *$ & 0.32 & 0.13 & \\
\hline $\mathrm{R}^{2}$ & 0.07 & & & 0.18 & & & 0.09 & & & 0.04 & & \\
\hline $\mathrm{N}$ & 1401 & & & 1401 & & & 1401 & & & 1401 & & \\
\hline
\end{tabular}

Source: FYAR data, 2012, two campuses at a large Midwestern university 
Tables $5 \mathrm{a}$ and $5 \mathrm{~b}$ display the service regressions for the external service categories. We find that women reportedly perform more service than men in two categories: community service and national service. National service here is distinct from service to professional organizations (a service activity may not be counted in more than one category), and might thus consist of activities such as participation on review panels.

Table 5a. Regressions with Specific External Service Activity Categories (Community/Public, State, Regional and National) as Dependent Variable

\begin{tabular}{|c|c|c|c|c|c|c|c|c|c|c|c|c|}
\hline \multirow[b]{2}{*}{ Variables } & \multicolumn{3}{|c|}{ Community/Public } & \multicolumn{3}{|c|}{ State } & \multicolumn{3}{|c|}{ Regional } & \multicolumn{3}{|c|}{ National } \\
\hline & B & SE & sig & $\mathrm{B}$ & SE & sig & B & SE & sig & B & SE & sig \\
\hline \multicolumn{13}{|l|}{ Gender } \\
\hline Female & 0.22 & 0.08 & $* *$ & 0.01 & 0.02 & & -0.01 & 0.02 & & 0.31 & 0.09 & $* *$ \\
\hline \multicolumn{13}{|l|}{ Rank } \\
\hline Full & -0.07 & 0.10 & & 0.04 & 0.03 & & -0.02 & 0.02 & & 0.33 & 0.11 & $* *$ \\
\hline Associate & 0.02 & 0.10 & & 0.02 & 0.03 & & -0.01 & 0.02 & & 0.04 & 0.11 & \\
\hline \multicolumn{13}{|l|}{ Race/Ethnicity } \\
\hline Black/Afr Amer & 0.03 & 0.17 & & -0.04 & 0.05 & & -0.06 & 0.04 & & 0.05 & 0.19 & \\
\hline Hispanic & -0.12 & 0.22 & & 0.08 & 0.06 & & -0.04 & 0.05 & & -0.14 & 0.23 & \\
\hline Asian & -0.20 & 0.12 & & -0.05 & 0.03 & & -0.06 & 0.03 & $*$ & 0.12 & 0.13 & \\
\hline Other, non-White & -0.22 & 0.31 & & 0.03 & 0.09 & & -0.09 & 0.07 & & -0.26 & 0.34 & \\
\hline \multicolumn{13}{|l|}{ Disciplinary Area } \\
\hline Education & -0.11 & 0.16 & & 0.12 & 0.04 & $* *$ & -0.02 & 0.03 & & 0.63 & 0.17 & $* *$ \\
\hline Business & -0.17 & 0.16 & & -0.07 & 0.04 & & -0.04 & 0.03 & & -0.74 & 0.17 & $* *$ \\
\hline Law & -0.49 & 0.38 & & -0.06 & 0.11 & & 0.02 & 0.08 & & -0.58 & 0.41 & \\
\hline Public Policy & 0.72 & 0.23 & $* *$ & 0.13 & 0.06 & & 0.00 & 0.05 & & -0.43 & 0.25 & \\
\hline Fine Arts & 0.05 & 0.14 & & 0.02 & 0.04 & & 0.08 & 0.03 & $*$ & -0.65 & 0.15 & $* *$ \\
\hline Social Sciences & -0.11 & 0.12 & & -0.08 & 0.03 & $*$ & -0.02 & 0.03 & & -0.38 & 0.13 & $* *$ \\
\hline Natural Sci/Math & -0.33 & 0.12 & $* *$ & -0.03 & 0.03 & & -0.03 & 0.03 & & -0.31 & 0.13 & $*$ \\
\hline Commun/Journal & -0.30 & 0.22 & & 0.02 & 0.06 & & 0.00 & 0.05 & & -0.14 & 0.23 & \\
\hline Tourism/Phys Ed & -0.56 & 0.52 & & 0.00 & 0.15 & & 0.17 & 0.11 & & -0.27 & 0.56 & \\
\hline \multicolumn{13}{|l|}{ Campus } \\
\hline Trad Research & -0.31 & 0.09 & $* *$ & -0.10 & 0.02 & $* *$ & -0.07 & 0.02 & $* *$ & 0.11 & 0.10 & \\
\hline Constant & 0.95 & 0.13 & $* *$ & 0.16 & 0.04 & $* *$ & 0.14 & 0.03 & $* *$ & 0.72 & 0.14 & $* *$ \\
\hline $\mathrm{R} 2$ & 0.04 & & & 0.03 & & & 0.03 & & & 0.07 & & \\
\hline $\mathrm{N}$ & 1401 & & & 1401 & & & 1401 & & & 1401 & & \\
\hline
\end{tabular}

Source: FYAR data, 2012, two campuses at a large Midwestern university 
Table 5b. Regressions with Specific External Service Activity Categories (International, Economic Development, Life Sciences, Professional Organizations) as Dependent Variable

\begin{tabular}{|c|c|c|c|c|c|c|c|c|c|c|c|c|}
\hline \multirow[b]{2}{*}{ Variables } & \multicolumn{3}{|c|}{ International } & \multicolumn{3}{|c|}{$\begin{array}{c}\text { Economic } \\
\text { Development }\end{array}$} & \multicolumn{3}{|c|}{ Life Sciences } & \multicolumn{3}{|c|}{$\begin{array}{l}\text { Professional } \\
\text { Organizations }\end{array}$} \\
\hline & B & SE & sig & $\mathrm{B}$ & SE & sig & B & SE & sig & B & SE & sig \\
\hline \multicolumn{13}{|l|}{ Gender } \\
\hline Female & -0.18 & 0.15 & & 0.01 & 0.01 & & -0.07 & 0.05 & & 0.08 & 0.19 & \\
\hline \multicolumn{13}{|l|}{ Rank } \\
\hline Full & 0.62 & 0.19 & $* *$ & 0.02 & 0.01 & & -0.12 & 0.06 & $*$ & 0.19 & 0.23 & \\
\hline Associate & 0.17 & 0.18 & & 0.02 & 0.01 & & -0.11 & 0.06 & & 0.25 & 0.22 & \\
\hline \multicolumn{13}{|l|}{ Race/Ethnicity } \\
\hline Black/Afr Amer & -0.10 & 0.32 & & -0.02 & 0.02 & & -0.08 & 0.10 & & -0.81 & 0.39 & $*$ \\
\hline Hispanic & 0.86 & 0.40 & $*$ & 0.03 & 0.03 & & -0.05 & 0.13 & & -0.49 & 0.48 & \\
\hline Asian & 0.25 & 0.22 & & -0.02 & 0.02 & & -0.10 & 0.07 & & 0.04 & 0.27 & \\
\hline Other, non-White & -0.11 & 0.57 & & 0.22 & 0.04 & $* *$ & -0.10 & 0.18 & & 0.02 & 0.70 & \\
\hline \multicolumn{13}{|l|}{ Disciplinary Area } \\
\hline Education & -0.04 & 0.29 & & -0.02 & 0.02 & & -0.09 & 0.09 & & 0.90 & 0.35 & $* *$ \\
\hline Business & -0.91 & 0.28 & $* *$ & 0.06 & 0.02 & $* *$ & -0.03 & 0.09 & & 1.23 & 0.35 & $* *$ \\
\hline Law & -0.25 & 0.69 & & -0.07 & 0.05 & & -0.13 & 0.22 & & -1.37 & 0.84 & \\
\hline Public Policy & -0.93 & 0.42 & $*$ & 0.00 & 0.03 & & -0.01 & 0.13 & & 1.28 & 0.51 & $*$ \\
\hline Fine Arts & -0.90 & 0.26 & $* *$ & 0.00 & 0.02 & & -0.10 & 0.08 & & -1.32 & 0.32 & $* *$ \\
\hline Social Sciences & -0.04 & 0.22 & & -0.02 & 0.02 & & -0.02 & 0.07 & & -0.07 & 0.27 & \\
\hline Natural Sci/Math & 0.03 & 0.22 & & 0.00 & 0.02 & & 0.06 & 0.07 & & 0.34 & 0.26 & \\
\hline Commun/Journal & 1.85 & 0.40 & $* *$ & 0.00 & 0.03 & & -0.06 & 0.13 & & 0.88 & 0.49 & \\
\hline Tourism/Phys Ed & 0.94 & 0.95 & & -0.02 & 0.07 & & -0.12 & 0.30 & & 0.46 & 1.16 & \\
\hline \multicolumn{13}{|l|}{ Campus } \\
\hline Trad Research & 0.28 & 0.16 & & -0.03 & 0.01 & $* *$ & -0.10 & 0.05 & $*$ & 0.40 & 0.20 & $*$ \\
\hline Constant & 0.75 & 0.23 & $* *$ & 0.03 & 0.02 & & 0.30 & 0.07 & $* *$ & 1.59 & 0.28 & $* *$ \\
\hline $\mathrm{R} 2$ & 0.06 & & & 0.03 & & & 0.01 & & & 0.05 & & \\
\hline $\mathrm{N}$ & 1401 & & & 1401 & & & 1401 & & & 1401 & & \\
\hline
\end{tabular}

Source: FYAR data, 2012, two campuses at a large Midwestern university

Results from the FSSE Analysis

Table 6 displays the results of the FSSE investigation. These results strongly mirror those obtained using the FYAR data. Women faculty report, on average, 0.6 hours more per week on service 
activities than men. As a robustness check, we ran an ordered logit using the original categorical variable as the outcome, and the results were qualitatively the same.

Table 6. Regression of Service Hours per Week on Female and Controls

\begin{tabular}{lccc}
\hline \multicolumn{1}{c}{ B } & SE & sig \\
\hline $\begin{array}{l}\text { Gender } \\
\quad \text { Female } \\
\text { Rank (ref. group }\end{array}$ & 0.6 & 0.22 & $* *$ \\
$\quad$ Full & 2.45 & 0.19 & $* *$ \\
$\quad$ Associate & 3.84 & 0.26 & $* *$ \\
Race/Ethnicity (ref. group White) & & \\
$\quad$ Black/Afr & & & \\
Amer & 0.67 & 0.55 & \\
$\quad$ Hispanic & 0.51 & 0.53 & \\
$\quad$ Asian & & & \\
American & -0.76 & 0.34 & $*$ \\
$\quad$ Native & & & \\
American & 1.93 & 1.06 & \\
$\quad$ Pacific Islander & 0.53 & 1.43 & \\
$\quad$ Other Minority & -0.5 & 0.56 & \\
Disciplinary area (ref. &
\end{tabular}

Disciplinary area (ref. group Arts and Humanities)

\begin{tabular}{lrrc} 
Biology & -1.14 & 0.35 & $* *$ \\
Physics & -1.42 & 0.25 & $* *$ \\
Social Sciences & -0.71 & 0.27 & $* *$ \\
Business & -0.73 & 0.36 & $*$ \\
Communications & 0.8 & 0.51 & \\
Education & 0.66 & 0.41 & \\
Engineering & -1.19 & 0.46 & $*$ \\
Health Fields & 0.1 & 0.45 & \\
Social Services & 0.28 & 0.71 & \\
Other & 1.23 & 0.56 & $*$ \\
Constant & 6.8 & 0.25 & $* *$ \\
\hline $\mathrm{R}^{2}$ & 0.09 & & \\
$\mathrm{~N}$ & 6,727 & & \\
\hline
\end{tabular}

$* p<0.05 ; * * p<0.01$

Institution fixed effects included

Standard errors presented below estimates are clustered at the institution level Source: FSSE 2014

As in the case of the FYAR analysis, interacting the covariates with the female indicator did not yield insights, with one exception relating to rank. In these data, female full professors report 
significantly more time spent on service than male full professors. Again, the main effect for the female indicator lost significance but the joint test of the indicator and all interactions was significant.

With regard to other covariates in the regression, we find that the rank variables exhibit the same pattern found in the FYAR, with associates spending the most time on service overall. In addition, faculty in fields of business and various sciences again appeared to devote fewer hours to service than those in arts and humanities.

\section{Discussion}

The FYAR results, closely corroborated by the FSSE results, leave little doubt as to the existence of a gender imbalance in faculty service loads. Both in the number of activities-as revealed in the FYAR - and in the amount of time spent on such activities - as revealed in the FSSE-women report doing more.

Several explanations for the service differences are possible. First, it may be that women are asked to do more service than are men. Second, women faculty may be less likely than their male counterparts to say "no" to service requests. Third, women may volunteer for more service than men. Fourth, women may be more likely to report their service activities than men.

With regard to the first two explanations - that women are asked to do more service than are men and that women are less likely to refuse service requests-Pyke (2011) argues that women are unable to refuse service requests due to a complex structure of gender inequity in academia. Since women are underrepresented on faculties, saying "no" tends to shift the burden of service to a small number of other female faculty whose concentration is in the junior ranks. Once tenure is achieved the protection from service disappears and female associates are hit with a larger number of requests than male associates. For female faculty, refusing service may engender resentment from other female faculty, whereas male faculty feel less structural pressure to serve and are instead likely to face criticism for too much rather than too little service from their male peers. 
With regard to the third explanation - that women volunteer for more service than men-some support exists in the literature. Vesterlund and colleagues (2011) analyzed responses to an email solicitation from the chair of the faculty senate at a large public university asking faculty to volunteer for several faculty senate committees. They found that women faculty at the associate and full professor levels were significantly more likely to volunteer for these committee assignments than male faculty. The difference was greater at the associate level than the full level. Although these committees represent only a segment of academic service, these responses do suggest some support for the notion that volunteerism is higher among women.

One could imagine several motives for this. It may be that by volunteering for campus-related service, women feel more able to control the type of service they provide and ensure a positive evaluation for service in merit reviews. Another possible reason for this might be a heightened perception on the part of women of the presence of an "internal" track into administration. In other words, women may be more likely than men to pursue opportunities within their institutions to advance into paid administrative roles. With the FYAR, we were able to explore this hypothesis to some extent. Recall that in our main analysis we excluded deans, directors, and department chairs in order to focus on uncompensated service. Using the full data set without these exclusions, we examined the likelihood that women held administrative positions. Using three separate logistic regressions to predict the likelihood that women held the positions of chair, dean, or director, we found that women were no more or less likely than men to hold such positions. Thus, the FYAR data do not suggest that such opportunities are greater for women than men. Therefore, unless women are using service to even their chances of gaining compensated service positions, the internal service track, as a potential explanation for a gender-service imbalance, does not appear to be supported by the data.

The fourth explanation - a gender difference in self-report bias-is difficult to assess with our data. One argument against this explanation is that our two different sources of data corroborate one 
another, despite the fact that they have very different stakes attached to them. The FYAR data are used in performance reviews and are linked to merit pay, whereas the FSSE data have no stakes attached. It seems unlikely that a tendency to underreport service on the part of male faculty would transcend both contexts.

\section{Conclusions and Implications}

We find strong evidence that women faculty perform more service than male faculty in academia, and that the service differential is driven particularly by participation in internal rather than external service. Thus, women faculty are shouldering a disproportionately large part of the burden of "taking care of the academic family," so to speak.

In the effort to achieve greater gender equity in academia, service has often been overlooked as a factor in the quest for parity, yet it merits close attention. It is an area of inequity that can be addressed relatively easily within institutions hoping to improve gender balance. Requests for service participation could be monitored and, if needed, allocated differently. Women faculty could be mentored to show more selectivity in their service-related choices and cultivate their ability to say "no" to requests. A simple increase in awareness of this issue may improve overall attitudes toward service loads, remove any trace of gender bias from service expectations, and enable both women and men to accept or decline service requests with equal ease and impunity.

Service loads have an impact on productivity in other areas of faculty effort such as research and teaching, and these latter activities can lead directly to salary differentials. Thus, in the urgency to redress not only differences in time use but compensation imbalances as well, the service imbalance is one that deserves to rise to the forefront of the discussion.

\section{References}

Bellas, M. L. \& Toutkoushian, R. K. (1999). Faculty time allocations and research productivity: gender, race and family effects." The Review of Higher Education 22(4), 367-390. 
Bird, S., Litt, J., \& Wang, Y. (2004). Creating status of women reports: Institutional housekeeping as "women's work," NWSA Journal, 16(1), 194-206.

Carr, P.L., Gunn, C.M., Kaplan, S.A., Raj, A., \& Freund, K.M. (2015). Inadequate Progress for Women in Academic Medicine: Findings from the National Faculty Study, Journal of Women's Health, 24(3), 190199.

Chisholm et al. (1999). A study of the status of women faculty in science at MIT. Massachusetts Institute of Technology. http://web.mit.edu/fnl/women/women.html, accessed on 4/21/16.

Link, A.N., Siegel, D.S., \& Bozeman, B. (2007). An empirical analysis of the propensity of academics to engage in informal university technology transfer, Industrial and Corporate Change, 16(4), 641-655.

Misra, J., Lundquist, J.H., Holmes, E., \& Agiomavritis, S. (2011). The ivory ceiling of service work. http://www.aaup.org/article/ivory-ceiling-service-work\#.VxIIJzArl2x, accessed on 4/21/16.

O'Laughlin, E.M. \& Bischoff, L.G. (2005). Balancing parenthood and academia: Work/Family stress as influenced by gender and tenure status. Journal of Family Issues, 26(1), 79-106.

O'Meara, K. (2002). Uncovering the values in faculty evaluation of service as scholarship, The Review of Higher Education, 26(1), 57-80.

Perna, L.W. (2001). Sex and race differences in faculty tenure and promotion. Research in Higher Education, 42(5), 541-567.

Porter, S. R. (2007). A closer look at faculty service: What affects participation on committees? The Journal of Higher Education, 78(5), 523-541.

Pyke, K. (2011). Service and gender inequity among faculty. Political Science \& Politics, 44(1), 85-87.

Russell, S., Fairweather, J., Hendrickson, R., \& Zimbler, L. (1991). Profiles of faculty in higher education institutions, 1988. Washington, DC: U.S. Department of Education Office of Educational Research and Improvement. (NCES 91-389)

Schiebinger, L. \& Gilmartin, S.K. (2010). Housework Is an Academic Issue, Academe, 96(1), 39-44

Singell, L. D., Jr., Lillydahl, J., \& Singell, L. D. Sr. (1996). Will changing times change the allocation of faculty time? Journal of Human Resources, 31(2), 429-449.

Street D.L., Baril, C.P., \& Benke, R.L. (1993). Research, teaching, and service in promotion and tenure decisions of accounting faculty. Journal of Accounting Education, 11, 43-60.

Toutkoushian, R.K., \& Conley, V.M. (2005). Progress for women in academe, yet inequities persist: Evidence from NSOPF:99. Research in Higher Education, 46(1), 1-28.

Toutkoushian, R.K., (1999). The status of academic women in the 1990s: No longer outsiders, but not yet equals, The Quarterly Review of Economics and Finance. 39, 679-69.

Vesterlund, L., Babcock, L., \& Weingart, L. (Unpublished draft). Breaking the glass ceiling with "no": Gender differences in declining requests for non-promotable tasks. 